\title{
Why do mutual fund expenses matter?
}

\author{
David Nanigian $^{*}$ \\ The American College
}

This Version: July 30, 2012

Comments are enormously welcome!

\begin{abstract}
* Assistant Professor of Investments, The American College, 270 South Bryn Mawr Avenue, Bryn Mawr, PA, 19010, Telephone: (610) 526-1324, Fax: (610) 516-1359, Email: david.nanigian@theamericancollege.edu. I am grateful to Phillip Gibson, seminar participants at The American College, and participants at the III World Finance Conference for their suggestions and to Melissa Cenneno for her excellent research assistance.
\end{abstract}

JEL Classification Codes: G02, G11, G23

Keywords: Mutual fund performance, Mutual fund fees, Mutual fund industry competition, Investor sophistication, Monitoring 


\begin{abstract}
This paper develops a theory that the intensity of investor monitoring explains much of the relationship between expenses and performance. I instrument for investor monitoring through the use of minimum initial purchase data to test the theory. I find that the highly publicized negative expense-performance relationship disappears among funds that cater to a sophisticated clientele of investors. I find that mainstream investors can use the existence of a share class with a high minimum initial purchase requirement as a signal of competitiveness. My results highlight the important influence investor monitoring has on the competitiveness of financial products.
\end{abstract}




\section{Introduction}

In the absence of market frictions, the price of a good should be commensurate with its quality. However, contrary to the predictions of Grossman and Stiglitz's (1980) equilibrium model, a plethora of empirical studies have made it a virtually stylized fact that the net-of-expense performance of a mutual fund is decreasing in expenses ${ }^{1}$. This puzzle begs the question of why mutual funds are uncompetitive in their offerings to the market. The purpose of this paper is to put forward and empirically analyze the possibility that the negative relationship between expenses and performance is explained by relaxed monitoring standards (or oversight) of investors.

There is a substantial body of literature which shows that most individuals who invest in mutual funds possess little knowledge of these products. In a survey of 3,386 investors, Capon, Fitzsimons, and Prince (1996) found that most of the individuals surveyed did not know the investment objective of their mutual fund or even if it is a domestic or international fund. Additionally, most of those surveyed considered fees to be of relatively little importance in the mutual fund selection process. In the analysis of a survey of 2,000 investors conducted by the Office of the Comptroller of the Currency and the Securities and Exchange Commission, Alexander, Jones, and Nigro (1998) found that most of those surveyed did not know their largest fund's expenses, even at the time they made their initial investment in it. Wallison and Litan (2007) also conducted a survey which showed similar results, even among individuals in the highest quintile of self-reported investment knowledge. When Wilcox (2002) performed a fund choice experiment on 50 investors, he found that most of his study participants paid less attention

\footnotetext{
${ }^{1}$ See, for example, Carhart (1997), Chevalier and Ellison (1999), Elton et al. (1993), Gruber (1996), and Harless and Peterson (1998) for evidence of this.
} 
to fees than past performance, even though past performance provides little indication of future performance.

In a related strand of the literature, Elton, Gruber, and Busse (2004) and Hortascu and Syverson (2004) examined the market for S\&P 500 index funds, where price should be the sole decision criteria, and found that more money has flowed into the most expensive funds than the least expensive funds. Moreover, a lack of attention to expenses in the market for index funds was also apparent in a study conducted by Choi, Laibson, and Madrian (2009) on two ivy-league campuses. When fees were clearly stated in a one-page tear sheet, only $20 \%$ of the 720 study participants, whose average SAT score was in the top decile of the general population, chose to invest only in the cheapest fund.

Taken together, prior research shows that people make rather uninformed decisions when selecting a mutual fund. However, according to the Investment Company Institute (2011), the median account balance of mutual funds was only $\$ 49,052$. This suggests that they make uninformed decisions because, as formalized in the next section of this paper, the improvement in portfolio performance from investing additional time into the fund search process is not large enough to justify their allocation of (costly) time to such tasks. Evans and Fahlenbrach (2012) find that institutional investors exhibit six times as much flow-expense sensitivity than their retail counterparts, which lends empirical support to the belief that monitoring intensity is increasing in capital allocation ${ }^{2}$.

In section 2, I develop my central theory through modeling the objective functions of investors and the companies that manage their assets, which are known by many practitioners as "fund providers." In section 3, I describe the data and methodology I employ to empirically test

\footnotetext{
${ }^{2}$ Siggelkow (2004) provides evidence of greater expense sensitivity among institutional investors.
} 
this theory. In section 4, I discuss the results from regression analysis. Section 5 concludes with practical implications and suggestions for future research.

\section{Theoretical Framework}

An individual should only exert costly effort in the mutual fund research process to the extent that the expected marginal increase in consumer surplus from a unit of time allocated to the task exceeds his or her opportunity cost of time.

$$
g_{r}>w
$$

where $g_{r}$ denotes the (monotonically decreasing) marginal product of labor in mutual funds research and $w$ denotes the marginal wage rate one commands in the labor market ${ }^{3}$. For the purpose of simplicity, I assume that $w$ is also equal to the marginal benefit from a unit of time spent engaging in leisurely activities. Because the characteristics of funds are rather opaque to the average individual, $g_{r}$ is increasing in one's level of specialization in improving riskadjusted returns through the fund search process, $s$. Additionally, one can only reap the benefits of specialization to the extent of their investable capital, $K^{4}$. Therefore,

$$
g_{r}=s K
$$

It follows that

$$
g_{\Delta s}>w
$$

\footnotetext{
${ }^{3}$ Examples of costly pursuits in the search process include reading literature on mutual funds and conversing with financial services professionals. To facilitate ease of reading, a summary of notation is provided in Appendix 1 (section 6.1).

${ }^{4}$ Ahn and Yoon (2011) surveyed 50 investors and found that time allocation to investment research is monotonically increasing in $k$.
} 
and

$$
\Delta s=f\left(K^{+}\right),
$$

where $g_{\Delta s}$ denotes the marginal product of labor in becoming educated about the mutual fund research process.

The objective of the investment management company is to maximize the following function for each of its funds

$$
P V(F C F)=\sum_{t=1}^{T} \frac{\sum_{i=1}^{I}\left(E X P_{i, t}-c_{i, t}\right) k_{i, t}}{(1+r)^{t}}
$$

where $P V(F C F)$ denotes the present value of the fund's free cash flows to the company, $E X P_{i, t}$ denotes the fund's operating expenses as a proportion of its total net assets (TNA) in period $t$ (expense ratio) assessed upon shareholder $i, c_{i, t}$ denotes the fund's cost of servicing shareholder $i$ in period $t$ as a proportion of the fund's TNA in the period, $r$ denotes the company's risk-adjusted rate at which it discounts the fund's cash flows, $I$ denotes the number of shareholders in the fund, $T$ denotes the number of periods for which the company expects to operate the fund, and $k_{i, t}$ denotes the capital invested in the fund by shareholder $i$ in period $t$. Without loss of generality

$$
k_{i, t}=f\left(K_{i, t}^{+}, \hat{\alpha}_{i, t}^{+}, g_{r_{i, t}}\right) \text {, }
$$

where $K_{i, t}$ denotes shareholder $i$ 's investable capital in period $t, \hat{\alpha}_{i, t}$ denotes shareholder $i$ 's contemporaneous estimate of the future net-of-expense performance that cannot be explained by common priced risk factors in asset returns, and $g_{r_{i, t}}$ denotes the marginal product of labor in 
mutual funds research of shareholder $i$ in period $t$. Because the completeness of one's information set regarding future fund performance is increasing in $g_{r}$,

$$
\lim _{\left(g_{r_{i}} \mid t\right) \rightarrow+\infty} \sigma_{\left(\widehat{\alpha}_{i} \mid t\right)}=0
$$

Free cash flows from a fund to the investment management company which operates it are a deadweight loss to investors, i.e.

$$
\frac{\Delta \alpha_{i, t}}{\Delta\left(E X P_{i, t}-c_{i, t}\right)}=-1
$$

$c_{i, t}$ can be decomposed into $c_{\alpha_{i, t}}$, which denotes the fund's cost of participating in the price discovery process to generate $\alpha$ for shareholders, and $c_{\mu_{i, t}}$, which denotes other costs associated with servicing shareholders, such as the costs associated with shareholder relations and maintaining shareholder records, so that

$$
c_{i, t}=c_{\alpha_{i, t}}+c_{\mu_{i, t}}
$$

and

$$
\alpha=f\left(c_{\alpha_{i, t}}^{+}\right)
$$

It follows that investment management companies will intentionally provide low $K$ myopes with mutual funds possessing marginal quality that is less than marginal price, i.e. $\Delta \alpha_{i, t}$ $<E X P_{i, t}$. This agency problem arises because the companies do not possess a sufficiently strong incentive to provide more competitive products to this rather complacent segment of the market of investors ${ }^{5}$. However, acting upon a more complete set of information, high $K$ sophisticates will demand a competitive product. Therefore, I hypothesize that a negative price-

\footnotetext{
${ }^{5}$ Theoretical work on this possibility in a more general setting is elegantly espoused in Gabaix and Laibson (2006).
} 
performance relationship only exists within a segment of the market where funds are exclusively offered to myopes. To test my hypothesis, I use funds' minimum initial purchase requirement as an instrument for investor sophistication and compare the expense ratioperformance relationship among funds with minimum initial purchase requirements of less than $\$ 100,000$ with their counterparts. The use of minimum initial purchase requirement as a proxy for sophistication follows James and Karceski (2006), who find that gross performance is increasing in minimum initial purchase requirement which lends support to the belief that managerial effort is increasing in the intensity of investor monitoring.

\section{Data and Methodology}

\subsection{Data}

Data on all open-end equity funds domiciled in the United States was collected from Morningstar Direct on September 28, 2011. Morningstar Direct is the most complete and timely database offered by Morningstar, Inc., a leading provider of mutual fund data.

Del Guercio and Reuter (2011) show that direct-sold mutual funds mainly compete on portfolio performance. Broker-sold funds are typically more expensive than direct-sold funds because they bundle portfolio management with personalized financial advice and these funds compete on both characteristics. Broker-sold and direct-sold funds are designed for different types of investors and as such there is little competition between the two types of funds. Del Guercio and Reuter (2011) conclude that empirical studies on mutual fund performance should 
censor the cross-section to only direct-sold funds. Therefore, I include only share classes that are classified by Morningstar as being "True No Load" in my study. Such share classes do not have a front-end sales load, contingent deferred sales load, or $12 b-1$ fee in excess of $0.25 \%$.

Sensoy (2009) finds that about one third of mutual funds have a prospectus-stated benchmark that does not match their style and he provides a compelling argument in favor of funds purposely comparing themselves to a benchmark that offers relatively low returns in order to attract investors. Therefore, I compare funds to the performance of benchmarks that are assigned by Morningstar's analysts rather than those that are stated in prospectus. This is because Morningstar mainly considers the recent portfolio holdings of a mutual fund in its selection of a benchmark index. A total of XYZ different benchmarks are used in this study, and they are listed in Appendix 2 (section 6.2).

\subsection{The Samples}

I employ two different methods of distinguishing funds that cater to sophisticates from those that cater to myopes. The first simply classifies a fund as a sophisticate type if the smallest minimum initial purchase requirement associated with any share class in the fund is at least $\$ 100,000$ and a myope otherwise. Following the principle of conservatism espoused in Evans and Fahlenbrach (2012), I classify funds that have at least one share class with a minimum initial purchase requirement of at least $\$ 100,000$ and another with a lower requirement as myope funds.

In the event there is missing minimum initial purchase requirement data on any share class in a fund, that fund is discarded from the sample. I then weight the monthly net-of-expense returns on each share class within a distinct fund portfolio by its contemporaneous TNA and 
summate the weighted returns across share classes to arrive at the fund's net return. I also weight the expense ratio by TNA, but because this is only reported on an annual basis, I simply weight it by the most recent TNA data available from Morningstar. Overall, this sample consists of 5,704 sophisticate funds and 317 myope funds. When restricted to only US Equity funds, it contains 2,403 sophisticate funds and 124 myope funds.

$86 \%$ of funds that have at least one share class with a minimum initial purchase requirement of at least $\$ 100,000$ comingle funds between their clienteles in the sense that they also have at least one share class with a lower requirement. Therefore, I employ an alternative methodology in which I group the net return and expense ratio data by not only Morningstar's distinct portfolio identifier but also by whether or not the minimum initial purchase requirement associated with the share class is at least $\$ 100,000$.

Example: Let us assume that a hypothetical fund offers four share classes, with minimum initial purchase requirements of $\$ 1,000,000, \$ 100,000, \$ 10,000$, and $\$ 1,000$ respectively. That fund will belong to both samples, yet the return and expense ratio data of the version that belongs to the sophisticate sample will be weighted by the TNA of only the share classes with minimum initial purchase requirements of $\$ 1,000,000$ and $\$ 100,000$. In contrast, the return and expense ratio data of the version that belongs to the myope sample will be weighted by the TNA of only the share classes with minimum initial purchase requirements of $\$ 10,000$ and $\$ 1,000$. 
The advantages of this methodology are twofold. First, it addresses the question of whether or not intense monitoring by sophisticates imposes a positive externality on their fellow myope shareholders, as alluded to in Evans and Fahlenbrach (2012). Second, it allows for a larger sample of funds that cater to sophisticates. Overall, this sample contains 1,295 funds. When restricted to only US Equity funds, it contains 542 funds.

\subsection{Mutual Fund Performance Estimation}

I gauge the performance of mutual funds through the use of benchmark-adjusted returns, which is the annual net return on a fund in excess of that of its analyst assigned benchmark over the period spanning September 2010 through August 2011. Funds lacking a continuous timeseries of monthly returns over the period are discarded. The rationale for using benchmarkadjusted returns, espoused in Cremers and Petajisto (2009), is that it allows an individual to directly compare the performance of a fund to an alternative product of similar risk characteristics that they could likely easily invest in.

Following the common practice of return-based style analysis in performance measurement I also employ two versions of Carhart's (1997) Four-Factor model for a subsample of funds with a Morningstar Broad Asset Class of U.S. Stock. The specification of the first model, which I refer to as the Benchmark-Adjusted Four-Factor model is

$$
r_{i, t=} \alpha_{i}+\beta_{\text {index }, i} r_{\text {index }, t}+\beta_{s m b, i} s m b_{t}+\beta_{\text {hml }, i} h_{m l}+\beta_{\text {mom }, i} \operatorname{mom}_{t}+\varepsilon_{i, t},
$$

where $r_{i t}$ is fund $i$ 's net-of-expense return in month $t$ in excess of the risk-free rate of interest, which is proxied by the interest rate on one-month Treasury bills (from Ibbotson Associates). $r_{i, t}$ 
is the return on the benchmark index assigned by Morningstar to fund $i$ in excess of the risk-free rate. $s m b_{t}$ and $h m l_{t}$ are the returns on Fama and French's (1993) portfolios that proxy for the common risk factors of size and book-to-market. mom $_{t}$ is the return on Carhart's (1997) portfolio that proxies for momentum in stock returns. Data on one-month Treasury bills, $s m b_{t}$, $h m l_{t}$, and $\mathrm{mom}_{t}$ are gathered from Kenneth French's website ${ }^{6} . \alpha_{i}$ captures fund $i$ 's net-ofexpense performance that cannot be explained by the factors in the model.

The specification of the second Four-Factor model, which I refer to as simply the FourFactor model is

$$
r_{i, t=} \alpha_{i}+\beta_{m, i} r_{m, t}+\beta_{s m b, i} s m b_{t}+\beta_{h m l, i} h m l_{t}+\beta_{m o m, i} m_{t}+\varepsilon_{i, t} .
$$

This model is identical to that of the Benchmark-Adjusted Four-Factor model except that $r_{\text {index,t }}$ is replaced with $r_{m, t}$, which is the value-weighted return on all stocks traded on the NYSE or NASDAQ in excess of the risk-free rate. It should be noted that alphas are annualized to percentage per year to facilitate ease of interpretation.

\subsection{Multivariate Regression Models}

To examine the relationship between expense ratio and performance, I run a series of cross sectional regressions of the performance metrics on expense ratio as well as a set of control variables from the literature. It should be noted that a lack of historical data on minimum initial purchase requirements precludes the employment of a panel method in regression analysis. The

\footnotetext{
${ }^{6}$ Details on the construction of the variables gathered from Kenneth French's website can be found at http://mba.tuck.dartmouth.edu/pages/faculty/ken.french/Data_Library/f-f_factors.html and http://mba.tuck.dartmouth.edu/pages/faculty/ken.french/Data_Library/det_mom_factor.html.
} 
control variables include turnover, logged TNA, logged TNA squared, the number of portfolio holdings, fund age (in years), inflow over the sample period, and the return on the analyst assigned benchmark index over the sample period. Details on the construction of these variables are provided in Appendix 3 (section 6.3). The values for turnover, the number of portfolio holdings, and fund age are based on the most recent data available from Morningstar Direct on the fund's largest share class at the end of the sample period. TNA is at the distinct portfolio level.

To control for residual correlations between funds that follow the same investment objective, I include dummy variables for each analyst assigned benchmarks and cluster standard errors by the benchmarks. It should also be noted that regressions with expense ratio omitted are also run to determine the extent to which variation in fund performance is explained by variation in expenses. However, funds missing expense ratio data are excluded from such regressions so as to not bias inferences when comparing the results between the models that include and exclude expense ratio.

\subsection{Descriptive Statistics}

Table I displays select percentile breakpoints of the distribution of minimum initial purchase requirements across all share classes of open-end funds domiciled in the United States. It also displays breakpoints for the smallest minimum initial purchase requirement (at the distinct portfolio level) across funds. $\$ 100,000$ was chosen as the threshold value for the "sophisticate" specification because it is over twice the value of the median account balance of mutual funds $(\$ 49,052)$ and because it allows for a decent sample size. 
Panel A of Table II conveys the $10^{\text {th }}$ percentile, mean, median, standard deviation, and $90^{\text {th }}$ percentile values of key fund characteristics for both the myope and sophisticate samples, where funds are sorted into samples based on their smallest minimum initial purchase requirement. Unsurprisingly, the sophisticates have lower expense ratios, presumably due to the lower cost of servicing a more concentrated group of shareholders. However, it is interesting to note that the differences in expense ratio are increasing in the percentile of expense ratio. For example, the difference in the $10^{\text {th }}$ percentile values between the two samples is 15 basis points yet the difference in the $90^{\text {th }}$ percentile values between the samples is 45 basis points. This lends credence to Gil-Bazo and Ruiz-Verdu's (2008) theory that only poor quality funds will charge excessive fees and as such they can only be sold to unsophisticated investors.

It is also interesting to note that the mean difference in benchmark-adjusted returns between the two samples is $0.88 \%$, yet the mean difference in expense ratios is $0.31 \%$. The lower expenses of the sophisticate funds can only explain about a third of their difference in performance, which suggests that managers of sophisticate funds exert more effort than managers of myope funds do as they are under greater scrutiny by their shareholders.

Panel B conveys the $10^{\text {th }}$ percentile, mean, median, standard deviation, and $90^{\text {th }}$ percentile values of key fund characteristics for the sample of "comingled funds" - funds with at least one share class with a minimum initial purchase requirement of at least $\$ 100,000$ and at least one other share class with a lower requirement. The mean expense ratio of the myopes is $30 \%$ less than that of the sophisticates, which is similar to the difference between the two groups in the full sample. 


\section{Results}

\subsection{Main Results}

The results from the full sample of funds, displayed in Table III, are consistent with the hypothesis. The impact of expenses on the performance of the myope funds is negative and highly statistically significant $(\mathrm{p}<0.001)$. Investors in these funds lose on average $\$ 1.51$ in net benchmark-adjusted return per each additional dollar they pay in operating expenses. In contrast, the impact of expenses on the performance of the sophisticate funds is not statistically significant $(\mathrm{p}=0.448)$.

It is also beneficial to analyze the differences in the explanatory power of expenses between the myopes and the sophisticates, which I gauge through (1) subtracting the r-squared associated with the regression that excludes expense ratio from that which includes expense ratio and (2) comparing this differential r-squared value between the myope and sophisticate subsamples. This calculation implies that expenses explain 2.18 times more of the variation in the performance of the myopes than of the sophisticates. In summary, the ability of expense to predict and to explain performance is only economically meaningful for the myopes.

\subsection{US Equity Fund Results}

To examine the robustness of the benchmark-adjusted returns to 4-factor model alphas, I run the previously employed models on a sample of US Equity Funds with two versions of 4factor model alphas as the dependent variable. The results from the regressions of Benchmark- 
Adjusted Four-Factor model alphas and (standard) Four-Factor model alphas are provided in Table IV in Panels A and B respectively. Consistent with the results from the benchmarkadjusted return regressions in the full sample, the impact of expenses on the performance of the myope funds is negative and highly statistically significant $(\mathrm{p}<0.001)$. At the margin, investors in these funds lose over twice what they pay in operating expenses. However, as in the prior set of results, the impact of expenses on the performance of the sophisticate funds is not statistically significant $(\mathrm{p}=0.544-0.600)$. It should also be noted that the expense ratio explains over five times as much of the variation in the performance of the myope funds than the sophisticate funds.

\subsection{Comingled Funds Results}

$86 \%$ of funds that have at least one share class with a minimum initial purchase requirement of at least $\$ 100,000$ comingle funds between sophisticate and myope clienteles in the sense that they also have at least one share class with a lower requirement. It would be interesting to examine the expense-performance relationship among the share classes of "comingled funds" that cater to myopes. To explore this, I censor the sample to only funds that have at least one share class with a minimum initial purchase requirement of at least $\$ 100,000$ and also have at least one share class with a lower requirement. I then group the net return and expense ratio data by not only Morningstar's distinct portfolio identifier but also by whether or not the minimum initial purchase requirement associated with the share class is at least $\$ 100,000$. Each fund then belongs to both the sophisticate sample as well as the myope sample, but the fund's return and expense data will depend on which sample it belongs to. 
Table V conveys two important results for the full sample of comingled funds. First, while the expense-performance relationships are statistically insignificant, it is interesting to note the price elasticity for the comingled sophisticates is $-0.27(\mathrm{p}=0.616)$, which of less magnitude than that which was observed within the sample of funds that only offer a share class for sophisticates in Table III $(-1.12, \mathrm{p}=0.448)$. This suggests that while there may be a lower aggregate level of shareholder monitoring within these funds than those that are offered exclusively to sophisticates, funds will only offer a class of shares for sophisticates if they feel that they can compete with funds that are offered exclusively to sophisticates. Second, the impact of expenses on the performance of myope funds that also have a sophisticate share class is not statistically significant $(\mathrm{p}=0.229)$. This implies that the monitoring activity conducted by sophisticate shareholders in such funds renders a positive externality to the myope shareholders.

Table VI conveys the results for US Equity comingled funds. The price elasticity for the comingled sophisticates is actually slightly positive $(0.43)$, albeit statistically insignificant $(\mathrm{p}=$ 0.642), in the regressions involving Benchmark-Adjusted Four-Factor model alphas. Consistent with the results from the full sample of comingled funds, the impact of expenses on the performance of myope funds that also have a sophisticate share class is not statistically significant $(\mathrm{p}=0.425)$. Similar results are obtained from the use of standard Four-Factor model alphas, conveyed in Panel B of Table VI. This provides further evidence that the sophisticate shareholders in comingled funds generate a positive externality to the myope shareholders. 


\section{Conclusion}

This paper established and empirically tested a theory that the intensity of investor monitoring influences the relationship between mutual fund expenses and performance. There are two major findings from this study. First, the negative relationship between expenses and performance, documented in the prior literature, disappears among funds with high minimum initial purchase requirements. This implies that fund managers will only "earn their keep" if they are subject to intense investor oversight. If investors desire to get what they pay for, they would be welladvised to more carefully evaluate funds prior to investing and to continue to monitor them afterwards. If they lack the skill needed to perform such tasks on their own, they should obtain assistance from a personal financial planner who is skilled in mutual funds research. If the aggregate intensity of investor monitoring increases then, as modeled in Gil-Bazo and RuizVerdu (2008), fund managers must exert greater effort in order to participate in the market for investor assets.

The second finding from this study is that among funds that have a share class with a minimum initial purchase requirement of less than $\$ 100,000$ and also have a share class with a higher minimum initial purchase requirement, a statistically significant expense-performance relationship does not exist. This is true even when only the expense and performance data of the share classes with the lower requirement is used. This is likely because funds will only offer a share class with a high minimum initial purchase requirement if they know that they can compete with other products that are targeted to the high net worth market in which, based on the theory developed in this paper, investors more closely monitor managed products. This implies that those with limited capital seeking to invest in an actively managed mutual fund should consider the existence of a high minimum initial purchase requirement share class to be a credible signal 
that a mutual fund is offering a competitive product to the market. A welfare analysis of the social benefits of investor monitoring has not been explored in this paper but is a ripe topic for future research. 


\section{Appendices}

\subsection{Notation}

\section{Summary of Notation}

\begin{tabular}{|c|c|}
\hline$\underline{\text { Variable }}$ & Description \\
\hline$g_{r}$ & The marginal product of labor in mutual funds research. \\
\hline$w$ & The marginal wage rate one commands in the labor market. \\
\hline$s$ & One's level of specialization in improving risk-adjusted returns through the fund search process. \\
\hline$K$ & The amount of one's investable capital. \\
\hline$g_{\Delta s}$ & The marginal product of labor in becoming educated about the mutual fund research process. \\
\hline$E X P_{i, t}$ & $\begin{array}{l}\text { The fund's operating expenses as a proportion of its TNA in period } t \text { (expense ratio) assessed upon } \\
\text { shareholder } i \text {. }\end{array}$ \\
\hline$\hat{\alpha}_{i, t}$ & $\begin{array}{l}\text { Shareholder } i \text { 's estimate of the future net-of-expense performance that cannot be explained by common } \\
\text { priced risk factors in asset returns. }\end{array}$ \\
\hline$c_{i, t}$ & The fund's cost of servicing shareholder $i$ in period $t$ as a proportion of the fund's TNA in the period. \\
\hline$c_{\alpha_{i, t}}$ & $\begin{array}{l}\text { The fund's cost of participating in the price discovery process in period } t \text { as a proportion of the fund's } \\
\text { TNA in the period. }\end{array}$ \\
\hline$c_{\mu_{i, t}}$ & $\begin{array}{l}\text { The fund's costs that are not associated with participating in the price discovery process in period } t \text { as a } \\
\text { proportion of the fund's TNA in the period. }\end{array}$ \\
\hline$P V(F C F)$ & $\begin{array}{l}\text { The present value of a fund's free cash flows to the investment management company that operates the } \\
\text { fund. }\end{array}$ \\
\hline$r$ & The investment management company's risk-adjusted rate at which it discounts its fund's cash flows. \\
\hline$I$ & The number of shareholders in a fund. \\
\hline$T$ & The number of periods for which an investment management company expects to operate a fund. \\
\hline$k_{i, t}$ & The capital invested by shareholder $i$ in period $t$. \\
\hline$r_{i t}$ & Fund $i$ 's net-of-expense return in month $t$ in excess of the risk-free rate. \\
\hline$r i_{t}$ & The return on the benchmark index assigned by Morningstar to fund $i$ in excess of the risk-free rate. \\
\hline$s m b_{t}$ & The returns on the Fama-French small-minus-big portfolio. \\
\hline$h m l_{t}$ & The returns on the Fama-French value-minus-growth portfolio. \\
\hline mom $_{t}$ & The returns on the Carhart momentum portfolio. \\
\hline$\alpha_{i}$ & $\begin{array}{l}\text { Captures fund } i \text { 's net-of-expense performance that cannot be explained by the factors in the asset pricing } \\
\text { model. }\end{array}$ \\
\hline$r_{m, t}$, & The value-weighted return on all stocked traded on the NYSE or NASDAQ in excess of the risk-free rate. \\
\hline
\end{tabular}




\subsection{Benchmarks}

Benchmark indices used in the regressions

\begin{tabular}{|c|c|}
\hline Benchmark Name & Benchmark Name \\
\hline BarCap Government 1-5 Yr TR USD & MSCI World NR USD \\
\hline BarCap Govt/Credit 1-5 Yr TR USD & MSCI World/Metals\&Mining USD \\
\hline BarCap Municipal 10 Yr 8-12 TR USD & MSCI World/Real Estate NR USD \\
\hline BarCap Municipal 20 Yr 17-22 TR USD & Morningstar Aggressive Target Risk \\
\hline BarCap Municipal 3 Yr 2-4 TR USD & Morningstar Lifetime Moderate 2010 \\
\hline BarCap Municipal California Exempt TR & Morningstar Lifetime Moderate 2015 \\
\hline BarCap Municipal New York Exempt TR & Morningstar Lifetime Moderate 2020 \\
\hline BarCap US Agg Bond TR USD & Morningstar Lifetime Moderate 2025 \\
\hline BarCap US Government Long TR USD & Morningstar Lifetime Moderate 2030 \\
\hline BarCap US Government TR USD & Morningstar Lifetime Moderate 2035 \\
\hline BarCap US Govt/Credit 5-10 Yr TR USD & Morningstar Lifetime Moderate 2040 \\
\hline BarCap US Govt/Credit Long TR USD & Morningstar Lifetime Moderate 2045 \\
\hline BarCap US Treasury US TIPS TR USD & Morningstar Lifetime Moderate 2050 \\
\hline BarCap US Universal TR USD & Morningstar Lifetime Moderate Income \\
\hline BofAML Convertible Bonds All Qualities & Morningstar Moderately Aggr Target Risk \\
\hline BofAML US HY Master II TR USD & Morningstar Moderately Cons Target Risk \\
\hline BofAML US Treasury Bill 3 Mon & Morningstar SEC/Technology TR USD \\
\hline BofAML USD LIBOR 3 Mon CM & Russell 1000 Growth TR USD \\
\hline Citi ESBI Capped Brady USD & Russell 1000 TR USD \\
\hline Citi WGBI NonUSD USD & Russell 1000 Value TR USD \\
\hline DJ UBS Commodity TR USD & Russell 2000 Growth TR USD \\
\hline DJ US Financial TR USD & Russell 2000 TR USD \\
\hline DJ US Health Care TR USD & Russell 2000 Value TR USD \\
\hline DJ US Select REIT TR USD & Russell 3000 TR USD \\
\hline DJ US Telecom TR USD & Russell China TR USD \\
\hline DJ Utilities Average TR USD & Russell Mid Cap Growth TR USD \\
\hline MSCI AC Far East Ex Japan NR USD & Russell Mid Cap Value TR USD \\
\hline MSCI AC World Ex USA NR USD & S\&P 1500 Cons Discretionary TR \\
\hline MSCI EAFE Growth NR USD & S\&P 1500 Cons Staples TR \\
\hline MSCI EAFE Value NR USD & S\&P 1500 Energy TR \\
\hline MSCI EM Latin America USD & S\&P 1500 Industrials TR \\
\hline MSCI EM NR USD & S\&P Diversified Trends Indicator TR \\
\hline MSCI Europe NR USD & S\&P MidCap 400 TR \\
\hline MSCI Japan NR USD & S\&P North American Natural Resources TR \\
\hline MSCI Pacific NR USD & USTREAS CD Sec Mkt 6 Mon \\
\hline MSCI World Ex US NR USD & \\
\hline
\end{tabular}




\subsection{Independent Variables}

\section{Description of independent variables used in the regressions}

\begin{tabular}{|c|c|}
\hline Variable & Description \\
\hline$\overline{\text { Expenses }}$ & $\begin{array}{l}\text { The percentage of fund assets used to pay for operating expenses and management fees, including } 12 \mathrm{~b}- \\
1 \text { fees, administrative fees, and all other asset-based costs incurred by the fund, except brokerage costs. } \\
\text { Fund expenses are reflected in the fund's NAV. Sales charges are not included in the net expense ratio } \\
\text { but expense waivers are. The net expense ratio for fund of funds only includes the wrap or sponsor fees, } \\
\text { and does not include the underlying fund fees. }\end{array}$ \\
\hline $\log (\mathrm{TNA})$ & The logarithm of the net assets of the mutual fund. \\
\hline$(\log (\mathrm{TNA}))^{2}$ & The squared value of $\log (\mathrm{TNA})$. \\
\hline Number of holdings & The net number of holdings in the portfolio. \\
\hline Fund age & The number of years since a fund was first offered. \\
\hline Inflow, $\mathrm{t}-1$ to $\mathrm{t}$ & $\operatorname{INFLOW}_{i}=\frac{\sum_{t=1}^{12}\left[T N A_{i, t}-T N A_{i, t-1} *\left(1+r_{i, t}\right)\right]}{T N A_{i, 0}}$ \\
\hline Index Return, $\mathrm{t}-1$ to $\mathrm{t}$ & $\begin{array}{l}\text { The return on the fund's associated analyst assigned benchmark over the period spanning September } \\
2010 \text { through August } 2011 \text {. }\end{array}$ \\
\hline Benchmark dummies & Indicate the benchmark index assigned by Morningstar's analysts to a fund. \\
\hline
\end{tabular}




\section{References}

Anh, D.H., \& Yoon, S.J. (2011). Endogenous Labor/Leisure/Investment Choice under Time Constraints. Journal of Financial and Quantitative Analysis, 46(4), 1157-1192.

Alexander, G. J., Jones, J. D., \& Nigro, P. J. (1998). Mutual fund shareholders: Characteristics, investor knowledge, and sources of information. Financial Services Review, 7(4), 301316.

Capon, N., Fitzsimons, G. J., \& Prince, R. A. (1996). An individual level analysis of the mutual fund investment decision. Journal of Financial Services Research, 10(1), 59-82.

Carhart, M. (1997). On persistence in mutual fund performance. Journal of Finance, 52(1), 5782.

Chevalier, J., \& Ellison, G. (1999). Are some mutual fund managers better than others? Crosssectional patterns in behavior and performance. Journal of Finance, 54(3), 875-899.

Choi, J. J., Laibson, D., \& Madrian, B. C. (2009). Why does the law of one price fail? an experiment on index mutual funds. The Review of Financial Studies, 23(4), 1405-1432.

Cremers, M., \& Petajisto, A. (2009). How active is your fund manager? A new measure that predicts performance. Review of Financial Studies, 22(9), 3329-3365.

Del Guercio, D., \& Reuter, J. (2011). Mutual fund performance and the incentive to invest in active management. Working paper. 
Elton, E. J., Gruber, M. J., \& Busse, J. A. (2004). Are investors rational? Choices among index funds. Journal of Finance, 59(1), 261-288.

Elton, E.J., Gruber, M.J., Das, S., \& Matthew, H. (1993). Efficiency with costly information: a reinterpretation of evidence from managed portfolios. Review of Financial Studies, 6(1), $1-22$.

Evans, R. B., \& Fahlenbrach, R. (2012). Institutional investors and mutual fund governance: Evidence from retail-institutional fund twins. Working paper.

Fama, E. F., \& French, K. R. (1993). Common risk factors in the returns on stocks and bonds. Journal of Financial Economics, 33(1), 3-56.

Gabaix, X., \& Laibson, D. (2006). Shrouded Attributes, Consumer Myopia, and Information Suppression in Competitive Markets. Quarterly Journal of Economics, 121(2), 505-540.

Gil-Bazo, J., \& Ruiz-Verdu. (2008). When Cheaper is better: Fee determination in the market for equity mutual funds. Journal of Economic Behavior and Organization, 67(3-4), 871885.

Grossman, S., \& Stiglitz, J. (1980). On the impossibility of informationally efficient markets. The American Economic Review, 70(3), 393-408.

Gruber, M. (1996). Another puzzle: the growth in actively managed mutual funds. Journal of Finance, 51(3), 783-810. 
Harless, D.W., \& Peterson, S.P. (1998). Investor behavior and the persistence of poorlyperforming mutual funds. Journal of Economic Behavior and Organization, 37(3), 257276.

Hortacsu, A. \& Syverson, C. (2004). Product differentiation, search costs, and competition in the mutual fund industry: A case study of s\&p 500 index funds. The Quarterly Journal of Economics, $119(2), 403-456$.

James, C., \& Karceski, J. (2006). Investor monitoring and differences in mutual fund performance. Journal of Banking \& Finance, 30(10), 2787-2808.

Sensoy, B. A. (2009). Performance evaluation and self-designated benchmark indexes in the mutual fund industry. Journal of Financial Economics, 92(1), 25-39.

Siggelkow, N. (2004). Caught between two principals. Working paper.

Wallison, P.J., \& Litan, R.E. (2007). Competitive Equity: A Better Way to Organize Mutual Funds. Washington, DC: AEI Press.

Wilcox, R. T. (2002). Bargain hunting or star gazing? Investors' preferences for stock mutual funds. Journal of Business, 76(4), 645-664.

2011 investment company fact book. (51 ed., pp. 1-252). Investment Company Institute.

Retrieved from http://www.ici.org/pdf/2011_factbook.pdf 


\section{Tables}

\section{Distribution of Minimum Initial Purchase Requirements}

\begin{tabular}{|c|c|c|}
\hline \multicolumn{3}{|c|}{$\begin{array}{l}\text { This table displays select nth percentile breakpoints (in dollars) of minimum initial } \\
\text { purchase requirements in the cross-section of both mutual fund share classes and } \\
\text { distinct portfolios. The minimum initial purchase requirement for a distinct } \\
\text { portfolio is considered to be the lowest minimum initial purchase requirement of } \\
\text { any share class in the portfolio. The data was gathered from Morningstar Direct on } \\
\text { September } 28,2011 \text {. }\end{array}$} \\
\hline Percentile & Share Class $(N=45,418)$ & Distinct Portfolio $(N=13,747)$ \\
\hline 0 & 0 & 0 \\
\hline 10 & 0 & 0 \\
\hline 20 & 500 & 0 \\
\hline 30 & 1,000 & 500 \\
\hline 40 & 1,000 & 1,000 \\
\hline 50 & 1,000 & 1,000 \\
\hline 60 & 2,000 & 1,000 \\
\hline 70 & 2,500 & 2,500 \\
\hline 80 & 3,000 & 2,500 \\
\hline 81 & 5,000 & 2,500 \\
\hline 82 & 5,000 & 2,500 \\
\hline 83 & 5,000 & 3,000 \\
\hline 84 & 10,000 & 4,000 \\
\hline 85 & 15,000 & 5,000 \\
\hline 86 & 25,000 & 5,000 \\
\hline 87 & 100,000 & 5,000 \\
\hline 88 & 100,000 & 5,000 \\
\hline 89 & 250,000 & 10,000 \\
\hline 90 & 250,000 & 10,000 \\
\hline 91 & $1,000,000$ & 15,000 \\
\hline 92 & $1,000,000$ & 25,000 \\
\hline 93 & $1,000,000$ & 100,000 \\
\hline 94 & $1,000,000$ & 100,000 \\
\hline 95 & $1,000,000$ & 250,000 \\
\hline 96 & $1,000,000$ & $1,000,000$ \\
\hline 97 & $2,500,000$ & $1,000,000$ \\
\hline 98 & $5,000,000$ & $1,000,000$ \\
\hline 99 & $5,000,000$ & $5,000,000$ \\
\hline 100 & $2,000,000,000$ & $2,000,000,000$ \\
\hline
\end{tabular}




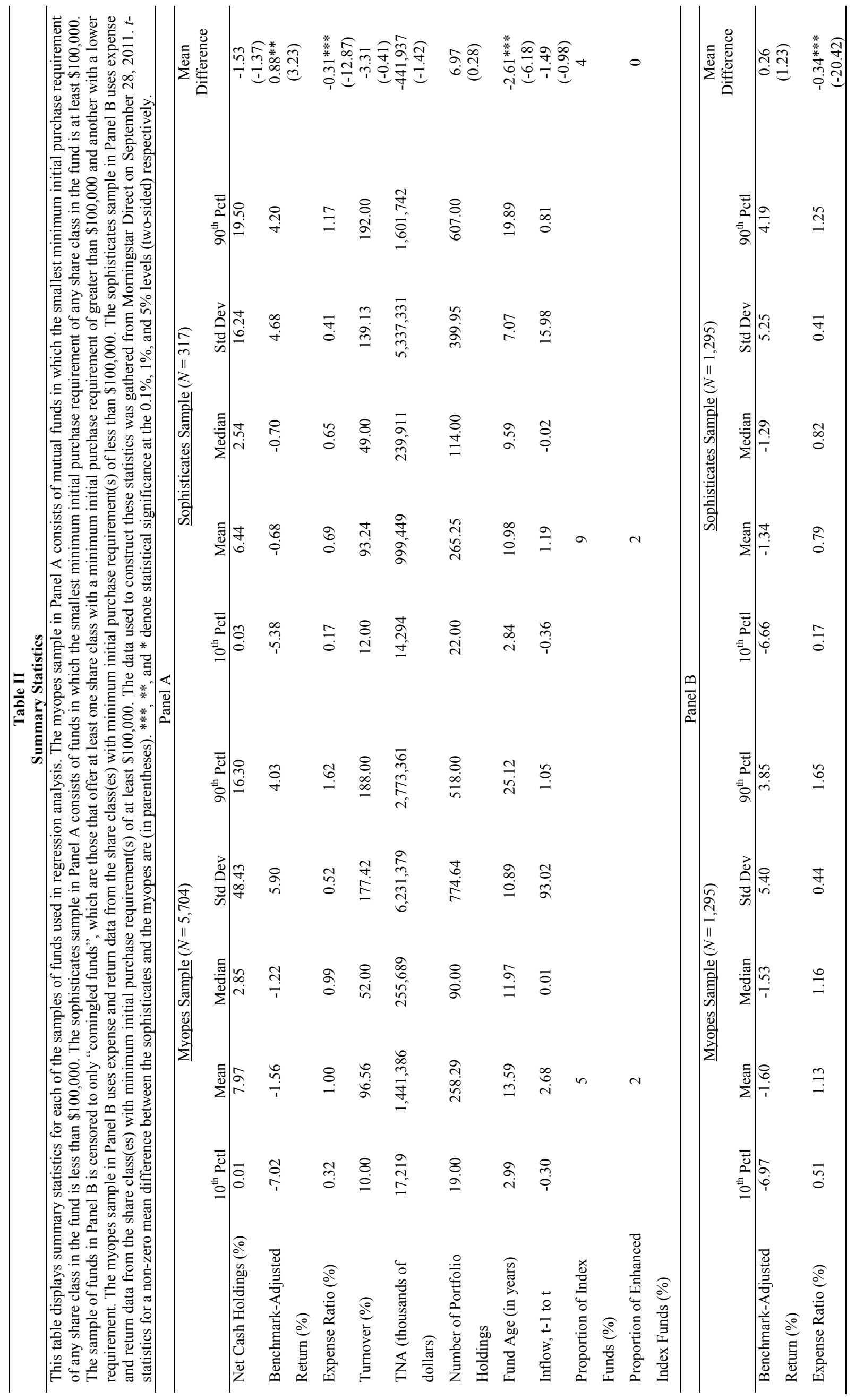




\section{Table III}

\section{Predictive regressions for benchmark-adjusted return}

\begin{tabular}{|c|c|c|c|c|}
\hline \multicolumn{5}{|c|}{$\begin{array}{l}\text { The myopes sample consists of mutual funds in which the smallest minimum initial purchase requirement of any share class in the fund } \\
\text { is less than } \$ 100,000 \text {. The sophisticates sample consists of funds in which the smallest minimum initial purchase requirement of any } \\
\text { share class in the fund is at least } \$ 100,000 \text {. The dependent variable is the cumulative net benchmark-adjusted return over September } \\
2010 \text { through August } 2011 \text {. Independent variable definitions are reported in Appendix } 3 \text {. The } t \text {-statistics (in parentheses) are based on } \\
\text { standard errors clustered by analyst assigned benchmark. ***, } * * \text {, and * denote statistical significance at the } 0.1 \%, 1 \% \text {, and } 5 \% \text { levels } \\
\text { (two-sided) respectively. }\end{array}$} \\
\hline & \multicolumn{2}{|c|}{ Myopes Sample } & \multicolumn{2}{|c|}{ Sophisticates Sample } \\
\hline & (1) & $(2)$ & (3) & (4) \\
\hline Expenses & & $\begin{array}{c}-0.0151^{* * *} \\
-3.63\end{array}$ & & $\begin{array}{l}-0.0112 \\
-0.76\end{array}$ \\
\hline Turnover & $\begin{array}{c}-0.0000^{* * *} \\
-2.95\end{array}$ & $\begin{array}{c}-0.0000^{*} \\
-2.43\end{array}$ & $\begin{array}{c}0.000 \\
0.77\end{array}$ & $\begin{array}{c}0.0000 \\
0.96\end{array}$ \\
\hline $\log (\mathrm{TNA})$ & $\begin{array}{c}0.0300 * * * \\
3.58\end{array}$ & $\begin{array}{c}0.0288 * * * \\
3.60\end{array}$ & $\begin{array}{c}-0.0208 \\
-0.70\end{array}$ & $\begin{array}{l}-0.0200 \\
-0.68\end{array}$ \\
\hline$(\log (\text { TNA }))^{2}$ & $\begin{array}{c}-0.0007 * * \\
-3.29\end{array}$ & $\begin{array}{c}-0.0007 * * \\
-3.42\end{array}$ & $\begin{array}{c}0.0006 \\
0.76\end{array}$ & $\begin{array}{c}0.0005 \\
0.72\end{array}$ \\
\hline Number of holdings/100 & $\begin{array}{l}0.0002^{*} \\
2.08\end{array}$ & $\begin{array}{l}0.0002^{*} \\
2.22\end{array}$ & $\begin{array}{c}-0.0001 \\
-0.23\end{array}$ & $\begin{array}{c}-0.0001 \\
-0.10\end{array}$ \\
\hline Fund age/100 & $\begin{array}{c}0.0113 \\
1.11\end{array}$ & $\begin{array}{l}0.0176 \\
1.65\end{array}$ & $\begin{array}{c}0.0461 \\
0.89\end{array}$ & $\begin{array}{c}0.0511 \\
0.97\end{array}$ \\
\hline Inflow, $\mathrm{t}-1$ to $\mathrm{t}$ & $\begin{array}{c}0.0000 \\
1.18\end{array}$ & $\begin{array}{c}0.0000 \\
1.22\end{array}$ & $\begin{array}{c}0.0006 \\
0.45\end{array}$ & $\begin{array}{c}0.0007 \\
0.48\end{array}$ \\
\hline Index Return, $\mathrm{t}-1$ to $\mathrm{t}$ & $\begin{array}{c}-0.0374^{*} \\
-2.48\end{array}$ & $\begin{array}{c}-0.0383^{*} \\
-2.57\end{array}$ & $\begin{array}{c}0.0689 \\
0.97\end{array}$ & $\begin{array}{c}0.0625 \\
0.88\end{array}$ \\
\hline Benchmark dummies & Yes & Yes & Yes & Yes \\
\hline $\begin{array}{l}\text { Observations } \\
\text { R-squared }\end{array}$ & $\begin{array}{c}5,704 \\
0.1851\end{array}$ & $\begin{array}{c}5,704 \\
0.1947\end{array}$ & $\begin{array}{c}317 \\
0.3477\end{array}$ & $\begin{array}{c}317 \\
0.3521\end{array}$ \\
\hline
\end{tabular}


Table IV

Predictive regressions for four-factor alphas

The dependent variable in Panel A is the annualized benchmark-adjusted four-factor alpha over September 2010 through August 2011. The dependent variable in Panel B is the annualized (standard) four-factor alpha over September 2010 through August 2011. The myopes sample consists of mutual funds in which the smallest minimum initial purchase requirement of any share class in the fund is less than $\$ 100,000$. The sophisticates sample consists of funds in which the smallest minimum initial purchase requirement of any share class in the fund is at least $\$ 100,000$. Independent variable definitions are reported in Appendix 3. The data was gathered from Morningstar Direct on September 28, 2011. The $t$-statistics (in parentheses) are based on standard errors clustered by analyst assigned benchmark. $* * *, * *$, and $*$ denote statistical significance at the $0.1 \%, 1 \%$, and $5 \%$ levels (two-sided) respectively.

\begin{tabular}{|c|c|c|c|c|}
\hline \multicolumn{5}{|c|}{ Panel A } \\
\hline & \multicolumn{2}{|c|}{ Myopes Sample } & \multicolumn{2}{|c|}{ Sophisticates Sample } \\
\hline & (1) & (2) & (3) & (4) \\
\hline Expenses & & $\begin{array}{c}-0.0212^{* * *} \\
-4.05\end{array}$ & & $\begin{array}{c}-0.0095 \\
-0.53\end{array}$ \\
\hline Turnover & $\begin{array}{c}-0.0001 * * \\
-3.56\end{array}$ & $\begin{array}{c}-0.0001 * * \\
-3.47\end{array}$ & $\begin{array}{c}-0.0001 \\
-0.60\end{array}$ & $\begin{array}{c}-0.0001 \\
-0.46\end{array}$ \\
\hline $\log$ (TNA) & $\begin{array}{c}0.0135^{*} \\
2.20\end{array}$ & $\begin{array}{c}0.0119 \\
1.65\end{array}$ & $\begin{array}{c}-0.0242 \\
-1.18\end{array}$ & $\begin{array}{c}-0.0238 \\
-1.13\end{array}$ \\
\hline$(\log (\mathrm{TNA}))^{2}$ & $\begin{array}{c}-0.0004 * \\
-2.09\end{array}$ & $\begin{array}{c}-0.0003 \\
-1.79\end{array}$ & $\begin{array}{c}0.0006 \\
1.27\end{array}$ & $\begin{array}{c}0.0006 \\
1.18\end{array}$ \\
\hline Number of holdings/100 & $\begin{array}{c}0.0005 \\
1.53\end{array}$ & $\begin{array}{c}-0.0002 \\
-0.39\end{array}$ & $\begin{array}{l}-0.0008 \\
-1.22\end{array}$ & $\begin{array}{c}-0.0009 \\
-1.70\end{array}$ \\
\hline Fund age/100 & $\begin{array}{c}-0.0035 \\
-0.30\end{array}$ & $\begin{array}{c}0.0027 \\
0.28\end{array}$ & $\begin{array}{c}-0.0345 \\
-.049\end{array}$ & $\begin{array}{c}-0.0318 \\
-0.45\end{array}$ \\
\hline Inflow, $\mathrm{t}-1$ to $\mathrm{t}$ & $\begin{array}{c}0.0001 \\
1.71\end{array}$ & $\begin{array}{c}0.0001 \\
1.73\end{array}$ & $\begin{array}{c}-0.0002 \\
-1.82\end{array}$ & $\begin{array}{c}0.0002 \\
-1.48\end{array}$ \\
\hline Index Return, $\mathrm{t}-1$ to $\mathrm{t}$ & $\begin{array}{c}0.0032 \\
0.28\end{array}$ & $\begin{array}{c}0.0089 \\
0.65\end{array}$ & $\begin{array}{c}0.0498 \\
1.35\end{array}$ & $\begin{array}{c}0.0419 \\
0.86\end{array}$ \\
\hline $\begin{array}{l}\text { Benchmark dummies } \\
\text { Observations } \\
\text { R-squared }\end{array}$ & $\begin{array}{c}\text { Yes } \\
2,403 \\
0.1249 \\
\end{array}$ & $\begin{array}{c}\text { Yes } \\
2,403 \\
0.1464 \\
\end{array}$ & $\begin{array}{c}\text { Yes } \\
124 \\
0.1083 \\
\end{array}$ & $\begin{array}{c}\text { Yes } \\
124 \\
0.1125 \\
\end{array}$ \\
\hline \multicolumn{5}{|c|}{ Panel B } \\
\hline & \multicolumn{2}{|c|}{ Myopes Sample } & \multicolumn{2}{|c|}{ Sophisticates Sample } \\
\hline & (1) & $(2)$ & (3) & (4) \\
\hline Expenses & & $\begin{array}{c}-0.0223^{* * *} \\
-4.07\end{array}$ & & $\begin{array}{c}-0.0109 \\
-0.62\end{array}$ \\
\hline Turnover & $\begin{array}{c}-0.0000 \\
-1.89\end{array}$ & $\begin{array}{c}-0.0000 \\
-1.62\end{array}$ & $\begin{array}{c}-0.0001 \\
-0.67\end{array}$ & $\begin{array}{c}-0.0001 \\
-0.51\end{array}$ \\
\hline $\log$ (TNA) & $\begin{array}{c}0.0159^{*} \\
2.13\end{array}$ & $\begin{array}{c}0.0111 \\
1.48\end{array}$ & $\begin{array}{c}-0.0212 \\
-1.10\end{array}$ & $\begin{array}{c}-0.0207 \\
-1.04\end{array}$ \\
\hline$(\log (\mathrm{TNA}))^{2}$ & $\begin{array}{c}-0.0004 \\
-1.92\end{array}$ & $\begin{array}{c}-0.0003 \\
-1.54\end{array}$ & $\begin{array}{c}0.0005 \\
1.20\end{array}$ & $\begin{array}{c}0.0005 \\
1.09\end{array}$ \\
\hline Number of holdings/100 & $\begin{array}{c}0.0004 \\
1.41\end{array}$ & $\begin{array}{c}-0.0003 \\
-0.52\end{array}$ & $\begin{array}{c}-0.0007 \\
-1.20\end{array}$ & $\begin{array}{c}-0.0009 \\
-1.73\end{array}$ \\
\hline Fund age/100 & $\begin{array}{c}0.0016 \\
0.14\end{array}$ & $\begin{array}{c}0.0081 \\
0.81\end{array}$ & $\begin{array}{c}-0.0293 \\
-0.41\end{array}$ & $\begin{array}{c}-0.0262 \\
-0.37\end{array}$ \\
\hline Inflow, $\mathrm{t}-1$ to $\mathrm{t}$ & $\begin{array}{c}0.0001 \\
1.35\end{array}$ & $\begin{array}{c}0.0001 \\
1.31\end{array}$ & $\begin{array}{c}-0.0002 \\
-1.64\end{array}$ & $\begin{array}{c}-0.0001 \\
-1.32\end{array}$ \\
\hline Index Return, $\mathrm{t}-1$ to $\mathrm{t}$ & $\begin{array}{c}0.0147 \\
1.17\end{array}$ & $\begin{array}{c}0.0207 \\
1.39\end{array}$ & $\begin{array}{c}0.0423 \\
1.20\end{array}$ & $\begin{array}{c}0.0332 \\
0.69\end{array}$ \\
\hline Benchmark dummies & Yes & Yes & Yes & Yes \\
\hline Observations & 2,403 & 2,403 & 124 & 124 \\
\hline R-squared & 0.1683 & 0.1893 & 0.3533 & 0.3574 \\
\hline
\end{tabular}


Table V

Predictive regressions for benchmark-adjusted return amongst "comingled funds"

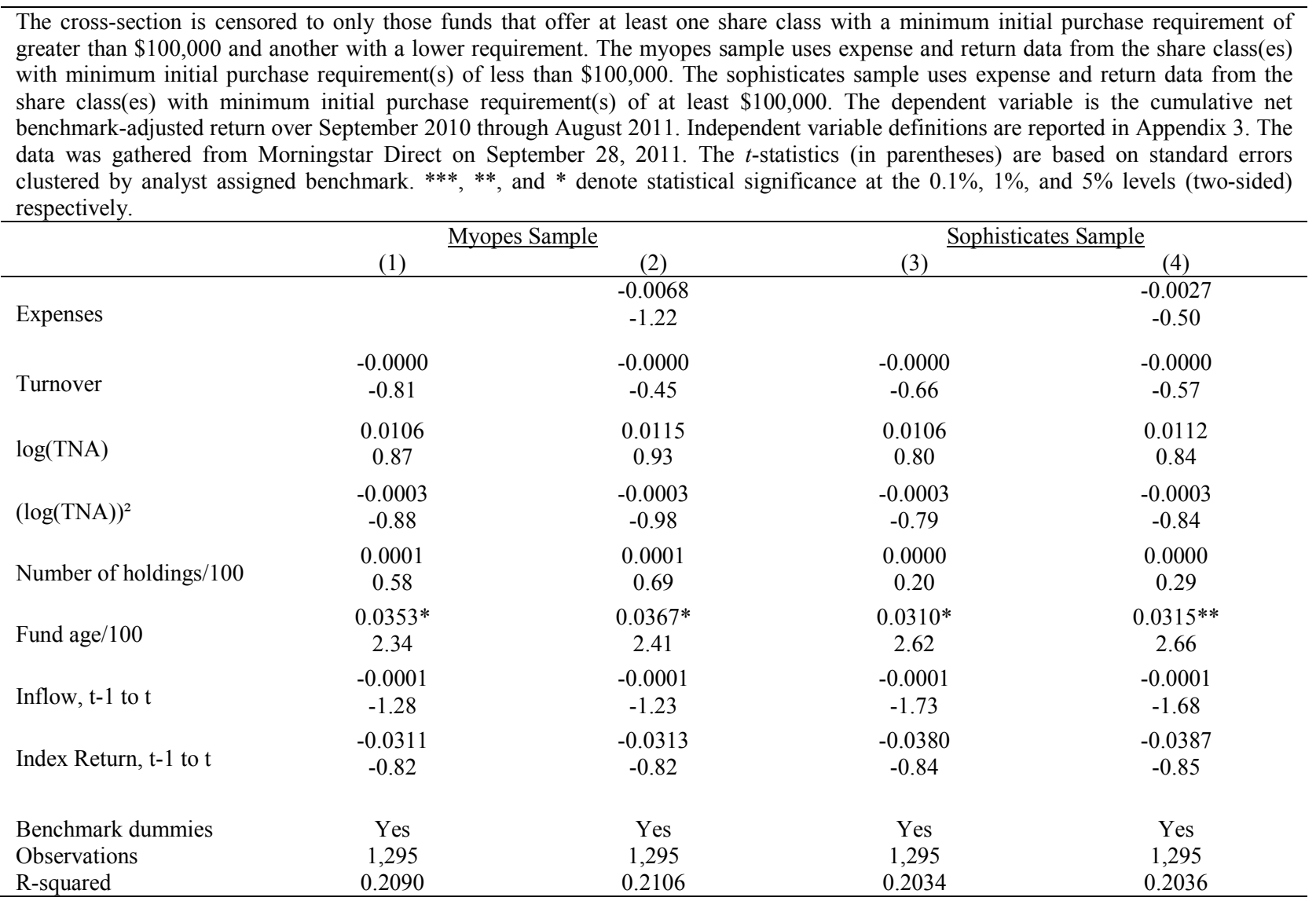




\section{Predictive regressions for four-factor alphas amongst "comingled funds"}

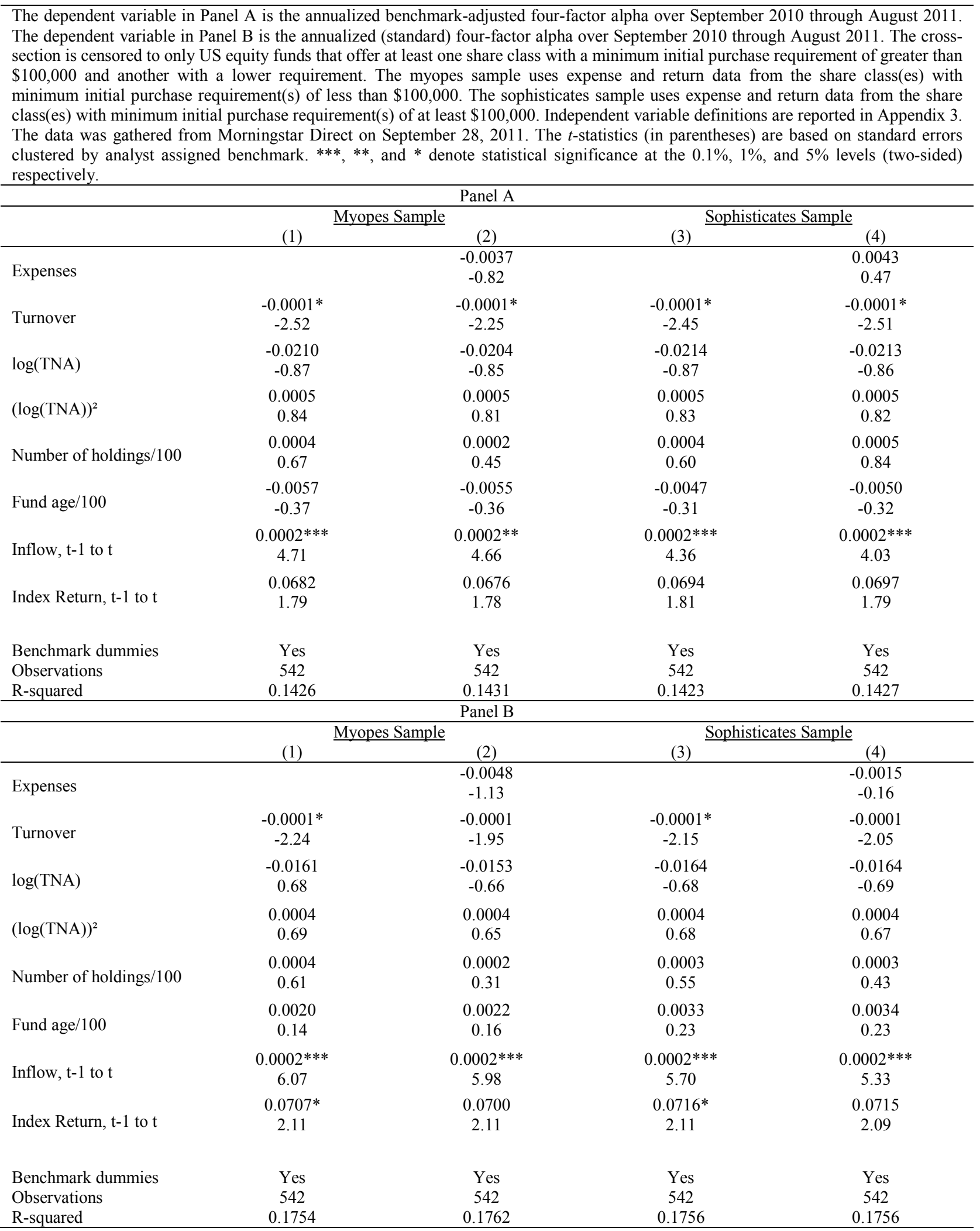

